\title{
A TUDATOS JELENLÉT ALAPÚ STRESSZREDUKCIÓS TECHNIKA (MBSR) HATÁSAIRÓL AZ IPOO-MODELL ASPEKTUSÁBÓL
}

\section{Szerző:}

Borbély Ildikó

Eszterházy Károly Egyetem

Első szerző e-mail címe: borbelyildiko89@yahoo.com

\author{
Lektorok:
}

Dr. Koncz István

Professzorok az Európai Magyarországért

Egyesület

Dr. Hanák Zsuzsanna

Eszterházy Károly Egyetem

Borbély Ildikó (2018): A tudatos jelenlét alapú stresszredukciós technika (MBSR) hatásairól az IPOO-modell aspektusából. Különleges Bánásmód, IV. évf. 2018/2. szám, 45-54. DOI 10.18458/KB.2018.2.45

\begin{abstract}
Absztrakt
E tanulmány a tudatos jelenlét alapú stressz redukciós módszer (MBSR, Mindfulness Based Stress Reduction) hatásait mutatja be az IPOO-modell alapján. A tanulmány célja, a tudatos jelenlét alapú stresszredukciós módszer hatásának ismertetése a pszichológiai jóllétre és a pszichológiai rugalmasságra, valamint bemutatásra kerülnek a téma kutatásainak eredményei is. A kutatások metaanalizise révén arra számítunk, hogy a tudatos jelenlét alapú stresszredukciós módszer hatására növekedni fognak a pszichológiai jóllét és a pszichológiai rugalmasság mutatói, $s$ a módszer eredményesen beépithetö az IPOO-modell alapú tanulásértelmezésbe is.
\end{abstract}

Kulcsszavak: IPOO-modell, MBSR, pszichológiai jóllét, pszichológiai rugalmasság

Diszciplina: pszichológia

\begin{abstract}
ABOUT EFFECTS OF MINDFULNESS BASED STRESS REDUCTION (MBSR) FROM ASPECTS OF IPOO-MODEL

The aim of this study is to show on the effects of Mindfulness Based Stress Reduction from viewpoint of the IPOO-model.
\end{abstract}

Keywords: IPOO-model, MBSR, psychological well being, psychological felxibility

Discipline: psychology

\section{Bevezetés}

E tanulmány a tudatos jelenlét alapú stressz redukciós módszer (MBSR, Mindfulness Based Stress Reductiom) hatásait mutatja be az IPOO-modell értelmezési keretében.

Az IPOO-modell egy funkcionális modell, leírása a következők szerint történik: Az I = Input, ami a beáramló ismereteket, adatokat jelenti, amelyek a $\mathrm{P}=$ Process alatt feldolgozásra 
kerülnek. Ebben a lépésben az összes beáramló adat, ismeret átdolgozásra kerül, ,ebben a tanulási modellben, az input és az output kapcsolatára alapozva három információ-feldolgozó lehetöséget különböztethetünk meg: a tanulás információfeldolgozó módja lehet reproduktiv, produktív vagy információ vesztést eredményezö." (Mezö F., Mezö K., 2014, 137.). Végül az $\mathrm{O}=$ Outputban, a már átdolgozott, kiáramló adatok és ismereteket jelennek meg. Mindezt áthatja az információ szervezése, rendezése az $\mathrm{O}=$ Organisation. A következőkben ezen az információ fel- és átdolgozó rendszeren keresztül mutatjuk be a tudatos jelenlét alapú stresszredukciós módszert. A tanulmány során foglalkozunk a technika értelmezésével, történetével, a technika alkalmazásval kapcsolatos kutatási eredményekkel valamint a technika alapvető elemeivel.

A tudatos jelenlét alapú stressz redukciós technika a buddhista hagyományból eredeztethető és több mint 2500 éves múltra tekint vissza. Legfőbb jellemzője egy belső tudatos éberség elérése, továbbá ennek a fenntartása. Egyfajta mélyebb önazonosság átélése, a jelen pillanatra való teljes koncentrálás. Egy mélyebb színtű tudatosság elérése sok előnnyel járhat. Jelenlegi tudatossági szintünket fejleszteni lehet és érdemes, hogy lehetőségünkben álljon életünk történéseinek, mélyebb tudatosabb megélése. Ebben a kalandban sokat segíthetnek a mindfulness technikák. A kontemplatív tudás és igény végigvonult az emberiség kultúrtörténetén, hol előtérbe került, hol pedig háttérbe szorult, de mindvégig jelen volt. 1979ben a massachusettsi egyetemen Jon Kabat-Zinn a buddhista hagyományból indult ki és kutatásainak alapját képezte e hagyomány elemeinek beépítése a nyugati gyógyászatba. Kutatásainak pozitív eredményeként megnyit egy Stresszcsökkentő Klinikát, ahol elkezdik alkalmazni, a tudatos jelenlét alapú stresszcsökkentő eljárást (MBSR). A módszer, a buddhizmus szenvedés kezelés alapeszméin és technikáin nyugszik, de mentes mindenféle filozófiai és vallási tartalomtól.

A tanulmány célja, a tudatos jelenlét alapú stressz redukciós módszer hatásának ismertetése a pszichológiai jóllétre és a pszichológiai rugalmasságra, de bemutatásra kerülnek az utóbbi évek kutatásainak eredményei is. Az MBSR programokat 8-9 illetve 10 hetesre tervezik. A program elkezdése előtt, illetve után a felmérések eredményei összehasonlításra kerülnek a változások kimutatására. A legtöbb kutatás kontrollcsoporttal dolgozik, melyben semmiféle beavatkozás nem történt, de találunk aktív kontroll csoportú kutatásokat is. Az IPOO-modell értelmezési rendszerében a kutatások végén arra számítunk, hogy a tudatos jelenlét alapú stresszredukciós módszer hatására növekedni fognak a pszichológiai jóllét és a pszichológiai rugalmasság mutatói (az általunk konkrétabban vizsgált esetben).

\section{A mindfulness, tudatos jelenlét}

A mindfulness fogalmát többféleképpen próbálták magyar nyelvre való fordítani: „tudatos jelenlét”, „,belső figyelem”, ,jelenlét”, „éberség”, „,éber figyelem”, „éber tudatosság”, „teljes odafigyelés”, „teljes tudatosság”. A továbbiakban a tanulmányban „tudatos jelenlét” fogalma kerül használatra.

A mindfulness elterjedése Kabat-Zinn (2009) érdeme, hatására a tudatos jelenlét gyakorlása elfogadottá és részévé vált a nyugati egészségügynek és klinikai ellátásnak. Megfogalmazásában „az éber figyelem egy régi buddhista gyakorlat, mely jelen életünkben mélységesen idöszerü. Ennek az idöszerüségnek semmi köze a buddhizmushoz vagy a buddhistává váláshoz. Csakis a felébredésröl szól, és arról, hogy az ember harmóniában éljen önmagával és a világgal. A segitségével megvizsgáljuk, hogy kik vagyunk, mérlegre tesszük a világnézetünket és a világban elfoglalt helyünket, és megtanuljuk nagyra becsülni életünk minden egyes pillanatának teljességét. De leginkább kapcsolatban vagyunk a valósággal" (Kabat-Zinn, 2009, 13.).

Shapiro és Carlson (2009) ezt azzal egészítette ki, hogy a tudatos jelenét szándékos 
tudatosság, nyitottság, elfogadás bármivel szemben, ami a jelen pillanatban felmerül.

Egy korábbi írásban Bishop, Lau, Shapiro, Carlson, Anderson, Carmody, Segal, Abbey, Speca, Velting és Devins (2004), a tudatos jelenlét folyamatjellegét hangsúlyozzák, s egy olyan folyamatként írják le, mely szabályozza a figyelmet olyanképpen, hogy egy minőségi, nem-elemző tudatosságot visz az éppen jelenlévő tapasztalatba, valamint nyitottságot, elfogadást és kíváncsiságot kapcsol ehhez a tapasztaláshoz.

\section{A tudatos jelenlét története}

A tudatos jelenlét technikájának története évezredes múltra tekint vissza. Az összes nagy világvallás története tanúskodik meglétéről. Morales Knight (2009) a következőket írja: „Úgy, a hinduizmusban, mint a buddhizmusban, a keresztény és muzulmán vallásokban egyaránt felismerték értékét és használták. Az emberiség hosszú és széleskörü tudatos jelenlét technikákkal kapcsolatos tapasztalata önmagáért beszél, jelzi a technika azon erős lehetőségét, hogy segítségével, a problémák megoldhatóak, egy belső térben. Az ázsiai kontemplatív tradíciók szülőatyja a hinduizmus volt. A kezdetekben a buddhizmus is ebből a tradícióból merített" (Morales Knight, 2009, 5.).

Silananda és Heinze szerint a buddhista tudatos jelenlét technika egyik igen lényeges alapeleme a légzés és az ülve végzett meditáció (idézi, Morales Knight, 2009). Az emberiség szellemtörténetében mindig is jelen volt a kontempláció, a meditáció, a vágy és a szükség, arra, hogy teljesen jelen legyünk a pillanatban, képesség a figyelem, az érzelmek és a gondolatok kontrolljára, kapcsolatra a „belsö én”-nel.

Kabat-Zinn (interjú, idézi Csörgö, 2009) több évtizedes, a molekuláris biológia alapú kutatásaiban a tudat és test közötti kapcsolatot vizsgálta a gyógyítás szempontjából. A meditáció hatását elemezte a krónikus fájdalomra és stresszre. 1979-ben Stresszcsökkentő Klinikát nyitott. A gyógyítás volt az elsődleges célja, de nem elhanyagolható cél az sem, hogy széles körben megismertesse a tudatos jelenlét alapú stresszcsökkentő módszert. A módszer a krónikus fájdalom kezelésére lett kifejlesztve, kognitív terápiával párosítva alkalmazzák a major depresszióba való visszaesések számának csökkentésére (Teasdale, Segal, Williams, Ridgeway, Soulsby és Lau, 2000), azonban a tudatos jelenlét technikájának alkalmazása egyre inkább beépült a pszichológiai gyakorlatba is

Shapiro (2009) elöreható lépésként tekintett arra, hogy a pszichológia elmélete és gyakorlata magába építse a tudatos jelenlét módszerét. Ezt a lépést nem csak a nyugati pszichológiára vonatkozóan tartotta szükségesnek, hanem az egész egészségvédelemre vonatkozóan. Shapiro úgy gondolta, hogy az első mérföldkő, hogy meg kell találni azt az átfordítást, azt a nyelvezetet, amely könnyen érthetővé teszi a tudósok, klinikusok és mindenki más számára a tudatos jelenlét mibenlétét (mivel sok esetben nehezen érthető, a mindfulness alapvetően non-dualista, olykor paradox szemlélete a nyugati embernek). Véleménye szerint, ahhoz, hogy a nyugati pszichológia számára elfogadhatóvá váljon a technika, elengedhetetlen, hogy a tudatos jelenlét meghatározása a nyugati pszichológia szövegkörnyezetében történjen. Emellett Shapiro (2009) célja volt megszüntetni vagy átírni, azt az elképzelést a nyugati szemléletben, hogy a meditáció valamiféle misztikus, mély spirituális és vallásos állapotot jelöl. Kabat-Zinn (2009) is ezt hangsúlyozta: „Amennyire tölem telik, kerülöm a "spirituális" szó használatát. Sem hasznosnak, sem szükségszerünek, sem helyénvalónak nem találom azt kórházi munkám során, amikor az éber figyelmet igyekszem bevezetni abba a gondolkodásmódba, amely az orvoslást és az egészségügyet uralja. Akkor sem veszem nagy hasznát, amikor más területeken dolgozom, mint például a multietnikus, belvárosi stresszcsökkentö klinikán, börtönökben, iskolákban, hivatalos szervezeteknél és sportolókkal.” (Kabat-Zinn, 2009, 111.) 
Shapiro (2009) kihangsúlyozza, a tudatos jelenlét kettős jellegét, melyet Carlson-nal együtt, az alábbiak szerint írtak le:

- Tudatos jelenlét-tudatosság: mint egy maradandó jelenléte a tudatosságnak, egy nyilvánvaló mély megértése a tudat szabadságának.

- Tudatos jelenlét-gyakorlat: mint rendszeres gyakorlása a szándékos nyitott, tudatos jelenlétnek, mely magában hordozza a tudat ismeretét és formálását.

\section{A tudatos jelenlét két-komponensü modellje}

Bishop és mtsai (2004) célja, hogy létrehozzanak egy konszenzust a teljes tudatosságon belül. Egy olyan megegyezést, mely által képesek lesznek kialakítani egy egyetemleges, müködőképes meghatározást a tudatos jelenléten belül, mely tesztelhető.

Bishop és mtsai (2004) egy, két komponensből álló tudatos jelenlét modellt indítványoznak. Az első komponens a tudatos jelenlét elsajátítása. Leszögezik, hogy a tudatos jelenlét nem egy relaxációs technika, hanem egyfajta mentális tréning, mely csökkenti a kognitív sebezhetőséget. A tudatos jelenlét gyakorlásán belül többféle technika létezik, ami közös mindegyikben, az maga a folyamat és a cél. Kabat-Zinn (2009) majd pár évvel később Segal, Williams, és Teasdale a következőképpen írják le a technikát: a figyelem fenntartása és egy adott dologra való összpontosítása, az egyik legalapvetőbb elem. Leírásuk szerint, a gyakorlás során a figyelem legáltalánosabban a légzésre vagy egy testi érzetre összpontosul. Ez általában hosszabb ideig tartó gyakorlást igényel, mivel a figyelemre alapvetően jellemző, hogy nagyon gyakran elkalandozik, egy gondolat vagy egy érzés irányába. Ilyenkor a gyakorlónak az a feladata, hogy csak szemlélje, egyszerúen csak tudomásul vegye, a megjelenő gondolatokat és érzéseket. Majd ahogy jöttek, úgy el is engedi őket és figyelmét ismét visszairányítja a légzésre vagy a testi érzetre. A gyakorlás alatt minden megjelenő gondolatot, dolgot és érzést, értékelés és ítélet nélkül fogadunk el (idézi Bishop és mtsai, 2004).

A második komponens átültetni ezt a fajta szemléletmódot a mindennapi életbe. A hétköznapokban amennyire csak lehetséges a figyelmet az itt és most-ra kell irányítani és ezt az állapotot fenntartani, majd kiterjeszteni minden cselekvésünkre, az egész nap folyamára, a légzést használva, egyfajta segítő eszközként. A teljes tudatosság állapotában a gondolatok és az érzések úgy jelennek meg, mint tudati események. Ez a viszonyulás, egyfajta „teret” képez az észlelés és a válasz között, így képessé válunk arra, hogy sokkal reflektívebb módon válaszoljunk a különböző helyzetekre. Ez egyfajta tudatos jelenlét a pillanatban.

A Bishop és mtsai által javasolt két komponensű modell, egyik eleme a figyelem önszabályozása. Véleményük szerint a mindfulness ott kezdődik, amikor képessé válunk teljes tudatosságot vinni az éppen aktuális tapasztalatba, amikor teljesen jelen vagyunk az itt és most-ban, tudatosak, éberek vagyunk azzal szemben, ami az itt és most-ban történik. Egyfajta fenntartott figyelemről van szó, a jelenben feloldódó éberségről. A megjelenő gondolatok és érzelmek úgy vannak felfogva, mint hullámok, amelyek a tudat folyamán felmerülnek. A figyelem átkapcsolása, magában foglalja a figyelem rugalmasságát, azt a képességet, hogy egyik tárgyról hirtelen a másikra kapcsol át (Jersild, 1927). Az elkalandozó figyelem, mindig vissza van irányítva a légzésre, vagy a testi érzetre. A tudatos jelenlét növekedésével, egyidejűleg növekszik a fenntartott figyelem és a figyelem átkapcsolása (idézi Bishop és mtsai, 2004). Bishop és mtsai kihangsúlyozzák, hogy a tudatos jelenlét, nem a gondolatok elnyomásán, kikapcsolásán alapszik, hanem azok puszta észlelésén. Ez a komponens segít, a depresszióval való megküzdésben is, a megjelenő gondolatok és érzések, szemlélve vannak, nem pedig elnyomva: „Amikor a depresszió kezd beszippantani bennünket, nagyon is érthetö okokból kifolyólag gyakran reagálunk azzal, hogy megpróbálunk megszabadulni az érzéseinktöl, s ezért elfojtjuk öket, vagy igyekszünk akaratlagosan lerázni 
öket magukról. Ennek során megbánt múltbeli eseményeket hozunk a felszínre, és a jövővel kapcsolatos aggodalmakat idézünk fel." (Williams és mtsai, 2011, 5).

A teljes jelenlét, az itt és most-ban kizárja a múlt sérelmeit és a jövő aggodalmait, egyszerüen csak feloldódunk a pillanatban. A két komponensű modell alapján, a mindfulness „egyik" meghatározásának Bishop és mtsai (2004) a következőt javasolták: az első komponens alapján a teljes tudatosság nem más, mint a figyelem önszabályozása, mely három elemet foglal magába: 1) a fenntartott figyelem, 2) a figyelem átkapcsolása és 3) a feldolgozó folyamatok gátlása. A feldolgozó folyamatok gátlása lehetetlenné teszi a tépelődést, az önmarcangolást.

A modell másik elemének, a tapasztalatokra való orientációt javasolják. Ezt a következőképpen fejtik ki: a tudat folyamán felmerülő gondolatokról, érzésekről és érzetekről a meditáció során csak egyszerüen tudomást veszünk. Ilyen módon kialakul egy elfogadó hozzáállás a felmerülő dolgokkal, gondolatokkal és érzésekkel szemben. Az elfogadás úgy határozható meg, mint nyitottság a közvetlen tapasztalatokkal, a jelen pillanat realitásával szemben (Roemer és Orsillo, 2002). Ebben az állapotban azt választjuk, hogy nyitottsággal és befogadással viszonyulunk mindenhez, ami éppen történik, ami éppen fel van kínálva az adott pillanatban. Hayes, Strosahl és Wilson tanulmánya szerint ez nyitottsághoz, elfogadáshoz és idővel a fájdalmas és kellemetlen gondolatok és érzések pszichológiai kontextusának megváltozásához vezet, valamint az új dolgokkal szembeni elkerülő magatartás mérsékléséhez (idézi Bishop és mtsai, 2004). A gyakorlás eredményeként Costa és McCrae (idézi Bishop és mtsai, 2004) szerint kialakul egy kíváncsi és elfogadó hozzáállás, az új eseményekkel szemben, egyfajta nyitott befogadás. Bishop és mtsai leszögezik, hogy a teljes tudatosságban az elfogadás egy olyan komponens, mely segít megbirkózni a nem kívánt, kellemetlen személyes tapasztalatokkal. A nyitottság és elfogadás azok az elemek, melyek növelik a pszichológiai rugalmasságot.

\section{Tudatos jelenlét alapú stresszcsökkentés (MBSR)}

A módszer, a tudatos jelenlét meditáció gyakorlatain alapul, ez az IPOO-modell alapján az Inputban valósulhatna meg. A tudatos jelenlét egy aktív, nyitott és elfogadó, szándékos élményszerü figyelem. Ebben az állapotban megfigyelhetjük aktuális érzelmeinket, testi érzeteinket és gondolatainkat. Maximálisan jelen vagyunk a pillanatban. Nyitottsággal és elfogadással fogadunk minden felmerülö érzést, gondolatot és érzetet. A cél, e nyitott tiszta figyelemi állapot minél hosszabb fenntartása és átvitele a hétköznapokba.

Kabat -Zinn kihangsúlyozta, hogy tévhit azon elképzelés, hogy a meditációban az agy „kiürítése”, a cél. A meditáció nem erről szól, hiszen a kiürítés, nem más, mint a problémáink elöl való elmenekülés (Csörgö, 2009). Ezzel szemben: „A tudatos figyelem gyakorlata arra ébreszt rá, mennyire fontos, hogy mélyen megéljük a gondolatainkat és érzéseinket. Nem kiüríteni, hanem lecsillapitani kell elménket, miközben éberen figyelünk magunkra. Így olyan problémákkal találkozhatunk, melyek elöl eddig kitértünk, nem foglalkoztunk vele, pedig mélyen bennünk lakoznak és hatással vannak ránk. Éberen kell tehát megélnünk a pillanatnyi idöt, s észrevennünk a jelen szépségeit" (Kabat -Zinn 2009, 15,).

A módszer annak ellenére, hogy a krónikus fájdalom kezelésére lett kifejlesztve (KabatZinn, 1982) hatásosnak bizonyult egészséges populáció körében, a stressz csökkentésében és a pszichológiai jóllét növelésében (Williams, Kolar, Reger, és Pearson, 2001). Brown és Rayn, továbbá Chambers, Lo és Allen (idézi Bishop és mtsai, 2004) kutatásai is azt bizonyítják, hogy egészséges populáció esetén a tudatos jelenlét gyakorlása a negatív hatások gyakoriságának és intenzitásának csökkenését eredményezte Továbbá pozitív eredmények születtek a szorongásos zavar (Roemer és Orsillo, 2002), valamint Wolfsdorf és Zlotnick kutatása alapján, a poszttraumás stressz zavar kezelésében (idézi Bishop és mtsai, 2004). 
A tudatos jelenlét gyakorlása réven, az IPOO-modell Output fázisában a következök jelennek meg: csökken, a személy mentális aktivitása és helyébe lép egyfajta belső nyugalom, ami már önmagában gyógyító hatással van a személyre, így a teljes tudatosság módszerét az oktatásban is eredményesen használhatják.

\section{Stressz és szorongás iskolai környezetben}

Kutatások azt mutatják, hogy igen magas a diákok között az iskolában átélt unalom (62,7\%), szorongás $(28,8 \%)$ és apátia (Albert, 2009). Ennek eredménye az a felismerés, hogy az iskola a diákok számára ne csak a tananyagot adjon át, hanem ezen kívül a megküzdésüket, a képességeik teljesebb kifejlesztését továbbá a pszichológiai jóllétüket elősegítő protektív tudást is közvetítsen.

Az iskolai légkör, a remélhetőleg nyugodtabb, biztonságosabb családi légkörhöz képest szorongással telibb, zsúfolt, zajos és nem kevés esetben agresszióval terhelt. A diákok több „felülről” érkező elvárasnak kell, hogy megfeleljenek, s előfordul, hogy a tanárok és a szülők felől érkező elvárások gyakran túl magasak. Az osztálytársak esetében pedig a beilleszkedés és a különböző rangsorok kialakulása jár sok feszültséggel és konfliktussal. Ezek mind számos stresszhelyzet okozói.

Ha a szervezet huzamosabb ideg van stressznek kitéve változások indulnak be. Az akut stresszreakció a szervezet menekülési reakciójának része, stresszhelyzetben a test felkészül a menekülésre vagy a harcra. A stressz hatására az adrenalin és a kortizol hormonszint megemelkedik, aktiválva a szervezet megküzdési erőforrásait. Ezzel párhuzamosan az immunrendszer gyengülni kezd. Ez a válaszreakció alapvetően evolucionális és az életbenmaradást támogatja. Azonban, ha a szervezet tartósan ki van téve ennek a válaszreakciónak, akkor a mellékvese idővel nem lesz képes elegendő kortizolt termelni és ez komoly egészségügyi problémákhoz vezethet. Emellett megterheli a szervezetet, hogy gyorsul a szívverés, emelkedik a vérnyomás és nő a vércukorszint is. A "küzdj, vagy menekülj" készenléti állapot, igen megterhelö fizikai és pszichikai szinten egyaránt. A mindfulness gyakorlatok hatására, nem maradnak el a stresszhelyzetek, de gyakoriságuk és intenzitásuk csökken. A stresszoldó technikák elsajátítására ezért alapvetően szükség van, már gyermek korban (Mező, 2011), a feleléstechnika és a stresszoldó technikák elsajátítása elősegítheti a szorongás csökkentését.

\section{Kutatási eredmények}

A továbbiakban kutatási eredmények alapján vizsgáljuk az MBSR módszer hatásait. Az MBSR hatásosnak bizonyult egészséges populáció körében a stressz csökkentésében és a pszichológiai jólét növelésében (Astin, 1997; Shapiro, Schwartz, és Bonner, 1998; Williams, Kolar, Reger, és Pearson, 2001), adaptívabb válaszadást eredményezett a stresszre (Davidson és mtsai.,2003). Továbbá egészséges populáció esetén az MBSR a negatív hatások gyakoriságának és intenzitásának csökkenését eredményezte (Brown és Rayn, 2003; Chambers, Lo, és Allen, 2008). Ezek alapján bizonyítást nyert, hogy az MBSR általában hozzájárul a pszichológiai jólét javulásához és annak növekedéséhez. Pozitív eredmények születtek érzelmi és viselkedési zavar (Kabat-Zinn, 1998), szorongásos zavar (Roemer és Orsillo, 2002; Wells, 1999; 2002), poszttraumás stressz zavar kezelésében (Wolfsdorf \& Zlotnick, 2001). Az MBSR gyakorlása alatt csökken a személy mentális aktivitása és helyébe lép egyfajta belső nyugalom, már önmagában ez gyógyító hatással van a személyre.

A tudatos jelenlét alapú stresszredukciós módszer révén létrejövő pszichológiai rugalmasság az érzelmi distressz csökkenését eredményezi, majd ez továbbvezet arra a szintre, ahol fejlődni kezd az érzelmi tolerancia (Bishop és mtsai, 2004). Az MBSR csökkenti 
a kognitív sebezhetőséget, gyakorlása révén fejlődik a figyelem fenntartása, rugalmassága, valamint a feldolgozó folyamatok gátlása. Rendszeres használata hozzásegít önmagunk belső történéseinek tudatosabb észleléséhez, valamint csökkenti az emocionális reaktivitást negatív érzésekre (Buchheld, Grossman, \& Walach, 2001).

A tudatos jelenlét alapú streszzredukciós módszer hatásaival kapcsolatos eredmény, hogy már egy nyolc hetes tréning hatására funkcionális- és strukturális változások tudtak kimutatni az agyban. Ezeket a változásokat föként a viselkedés- és érzelemszabályozásért felelös prefrontális kéregben és az érzelmi stresszreakciókért felelős amygdalában észlelték. Az elöbbiben aktivitásfokozódást és térfogat növekedést, az utóbbiban aktivitás- és térfogatcsökkenést tudtak kimutatni (Brewer, 2011). A neuroplaszticitás következtében a különböző idegi kapcsolatok és azok erőssége megváltozik és ezáltal átalakul az általuk ellátott funkció. A kevésbé használt képességek és az azért felelős idegi kapcsolatok csökkennek, a gyakran használtak ezzel szemben megerősödnek.

A következőkben négy napjainkban megjelenő kutatás bmutatására kerül sor. Felver és mtsai (2016) 28 alkalmazott mindfullness kutatást dolgozott fel. Céljuk a meglévő tudományos eredmények illetve elméletek felülvizsgálata és a jövőbeli kutatások irányának a megszabása volt. Mind a 28 tanulmányban a tudatos jelenlét alapú stresszredukciós módszert alkalmazták általános iskolai tanulók körében. A tudatos jelenlét alkalmazásával a kutatási eredmények alapján csökkenés mutatkozik a problémás viselkedést illetően $(n=6)$, a szorongás $(n=5)$, a depresszió $(n=4)$, az érzelmi zavar $(n=4)$, a figyelem $(n=4)$ és az öngyilkossági hajlandóság $(\mathrm{n}=1)$ esetén. Továbbá, növekedést mértek szociális interakció, elköteleződés, érzelmi szabályozás, optimizmus és coping terén. Kutatási módszertani hiányosságként jelenik meg, hogy egyetlen kutatásban sem alkalmaztak aktív kontrollcsoportot, továbbá a megismételhetőség problémája, valamint nem eléggé változatos mérési stratégiák alkalmazása.

Bakosh és mtsai (2016) vizsgálatuk során általános iskolában 8 hetes, napi 10 perces tudatos jelenlét tréninget alkalmaztak (audio formában). Megállapították, hogy 8 hetes tréning után szignifikáns javulás jelentkezett az olvasás, matematika és az írás téren, a kísérleti csoportban résztvevők körében, a kontrollcsoporthoz képest.

Miller, Borsatto és Al-Salom (2018) kutatásában 88 másod és harmadéves pszichológus hallgatók vett részt,. A kutatók egy 3 perces legzésgyakorlatot alkalmaztak, naponta egyszer, egy kurzus alkalmával féléven keresztül. A kontrollcsoporthoz képest a kísérleti csopor tagjai gyakrabban éltek át pozitív érzelmeket és a dekoncentráltság alacsonyabb szintjét mutatták. A hallgatók az egyetemen kívül is használták a légzési technikát és elmondásuk szerint a különbözö gyakorlatokban több örömöt leltek, pszichológiai jóllétüket illetően egyértelmü növekedés mutatkozott. A kutatók a jövőbeli kutatások figyelmébe ajánlják, annak feltérképezését, hogy hogyan lehetne a diákok rendelkezésére bocsájtani az egyetemi oktatás keretén belül ezt a gyakorlatot.

Végül egy tanárok $(\mathrm{N}=1001)$ körében végzett kutatás bemutatására kerül sor. A kutatás egyik elméleti kiindulópontja, a tanár-diák kapcsolat mint kulcsfontosságú előrejelzője, a diák szociális, emocionális képességeinek, és akadémiai előmenetelének. A kutatás célja, a tudatos jelenlét növelése volt a tanárok körében, annak érdekében, hogy a tanár-diák kapcsolat minősége javuljon. Összefüggést feltételeztek a tanár mindfulness szintje és a diákokkal való kapcsolatának minősége között, a konfliktuskezelés és közelség tekintetében. Továbbá megvizsgálaták, hogy ez összefügg-e a tanár depressziós skálájával és stressz szintjével. A kísérlet eredménye, hogy magasabb mindulness szint, magasabb minőségü tanár-diák kapcsolatot eredményez (kevesebb konfliktussal és nagyobb közelséggel), továbbá, hogy magasabb mindfulness szint alacsonyabb depresszió szinttel függ össze. Nem utolsó sorban jobb konfliktuskezelés magasabb mindfulness és alacsonyabb stressz szinttel korrelált a kutatásban (Becker, Gallagher és Whitaker, 2017). 


\section{Összegzés}

A tanulmányban végigkísértük a tudatos jelenlét alapú stresszredukciós módszer kialakulásának és fejlődésének történetét, kitérve a témával kapcsolatos pozitív kutatási eredményekre. Bemutattuk, a tudatos jelenlét alapú stresszredukciós módszer hatásait az IPOO-modell keretrendszerének értelmezésében. Továbbá egy leírását és értelmezését adtuk a tudatos jelenlét két-komponensủ modelljének. Megállapíthatjuk, hogy a rendszeresen használt MBSR módszer csökkentheti a felelés és dolgozatírás közben kialakult szorongást, ezáltal javíthatja a tanulási teljesítményt, így a módszer beépíthető az IPOO rendszerü tanulási technikák közé is.

A tudatos jelenlét következménye egy intenzívebb önmegfigyelés és a saját tapasztalatok állandóan változó folyamának nyitottabb, befogadóbb megfigyelése. Egy jobb és teljesebb megértés, a gondolatok és érzések természetét illetően. Tisztább rálátás arra, hogy az egyik tapasztalatból, hogyan ered a következő, hogy egy érzés hogyan ébreszt fel egy ítéletet, egy gondolatot, majd ez hogyan fokozza az adott (kellemetlen) érzést. Lehetőség arra, hogy tisztábban lássuk a kapcsolatot, a gondolatok, az érzések és a cselekvés között.

\section{IRODALOM}

Arch, J.J., Craske, M.G. (2006). Mechanisms of mindfulness: Emotion regulation following a focused breathing induction, Behaviour Research and Therapy. 44. 1849-1858

Albert, L.E. (2009). A drogfogyasztás prevenciója. Az integrált megelőzés elmélete és gyakorlata, Editura Presa Universitară Clujană, Cluj.

Bishop, S. R., Lau, M., Shapiro, S., Carlson, L., Anderson, N. D., Carmody, J., Segal, Z. V., Abbey, S., Speca, M., Velting, D., Devins, G. A. (2004). Mindfulness: A Proposed Operational Definition, Clinical Psychology: Science and Practice. V11 N3. FALL. 230241

Brandon D. Becker, Kathleen C. Gallagher és Robert C. Whitaker (2017). Teachers' dispositional mindfulness and the quality of their relationships with children in Head Start classrooms. Journal of School Psychology. 65.40-53.

Carmody, J., Baer, R.A. (2009). How long does a mindfulness-based stress reduction program need to be? A review of class contact hours and effect sizes for psychological distress. Journal of Clinical Psychology. 65. 627-638.

Carmody, J., Olendzki, N., Baer, R.A., Lykins, E.L.B. (2009). An empirical study of the mechanisms of mindfulness in a mindfulness-based stress reduction program. Journal of Clinical Psychology. 65. 613-626.

Carlin J. Miller, Julia Borsatto \&Patricia Al-Salom (2018). Testing a quick mindfulness intervention in the university classroom. Journal of Further and Higher Education. 1-9.

Christopher, M.S., Charoensuk, S., Gilbert, B.D., Neary, T.J., Pearce, K.L. (2009). Mindfulness in Thailand and the United States: A case of apples versus oranges? Journal of Clinical Psychology. 65. 590-612.

Csörgő Z., 2009: Gyógyító meditáció. http://www.mbsr.hu/cikkek/Termeszetgyogyasz_Jon_Kabat_Zinn.pdf (letöltve, 2018. 01. 20)

Joshua C. Felver, Cintly E. Celis-de Hoyos, Katherine Tezanos \& Nirbhay N. Singh.( 2016). A Systematic Review of Mindfulness-Based Interventions for Youth in School Settings. Mindfulness. 7.1.34-45. 
Judson A. Brewer, Patrick D. Worhunsky, Jeremy R. Gray, Yi-Yuan Tang, Jochen Weber és Hedy Kober (2011). Meditation experience is associated with differences in default mode network activity and connectivity. https://doi.org/10.1073/pnas.1112029108 (letöltve, 2018.02.01.)

Jersild, A.T. (1927). Mental set and shift. Archives of Psychology. 14. 89. 81

Kabat-Zinn, J. (2009): Bárhova mész, ott vagy. Éberségmeditáció, a mindennapi életben. Ursus Libris kiadó, Budapest

Kabat-Zinn, J. (1982). An outpatient program in behavioralmedicine for chronic pain patients based on the practice ofmindfulness meditation: Theoretical considerations and preliminary results. General Hospital Psychiatry. 4. 33-47.

Kuyken, W., Watkins, E., Holden, E., White, K., Taylor, R. S., Byford, S., Evans, A., Radford, S., Teasdale, J.D., Dalgleish, T. (2010). How does mindfulness-based cognitive therapy work? Behaviour Research and Therapy. 48. 1105-1112

Laura S. Bakosh, Renee M. Snow, Jutta M. Tobias, Janice L. Houlihan, Celestina BarbosaLeiker (2016). Maximizing Mindful Learning: Mindful Awareness Intervention Improves Elementary School Students' Quarterly Grade. Mindfulness. 7.1.59-67.

Linehan, M. M., Armstrong, H. E., Saurez, A., Allmon, D., Heard, H. L. (1991). Cognitive behavioral treatment of chronically parasuicidal borderline patients. Archives of General Psychiatry. 48. 1060-1064

Mező F. (2011a): Tanulás: diagnosztika és fejlesztés az IPOO-modell alapján. K+F Stúdió Kft., Debrecen

Mező F., Mező K. (2011): Kreatív és iskolába jár! K+F Stúdió Kft., Debrecen

Mező F., Mezö K. (2014): The IPOO-model of creative learning and the students information processing characteristics. Horizons of Psychology. 23, 136-144 obzorja.si/arhiv_clanki/2014/mezo_mezo.pdf (letöltve, 2018. 02. 28)

Morales Knight, L.F., 2009: Mindfulness: history, technologies, research, applications. https://allansousa.files.wordpress.com/2009/11/mindfulnessarticleluis.pdf (letöltve, 2018. 03. 01)

Nydahl, O. (2010): Ahogy a dolgok vannak. Jaffa kiadó, Budapest

Roemer, L., és Orsillo, S.M. (2002). Expanding our conceptualization of and treatment for generalized anxiety disorder: Integrating mindfulness/acceptance-based approaches with existing cognitive-behavioral models. Clinical Psychology: Science and Practice. 9. 5468.

Shapiro, S. L. (2009). The Integration of Mindfulness and Psychology, Journal of Clinical Psychology. 65. 6. 555-560.

Shapiro, S.L., Oman, D., Thoresen, C.E., Plante, T. G., Flinders, T. (2008). Cultivating Mindfulness: Effects on Well-Being, Journal of Clinical Psychology. 64. 7. 840-862

Shapiro, S.L., Carlson, L.E., Astin, J.A., Freedman, B. (2006). Mechanisms of mindfulness. Journal of Clinical Psychology. 62. 373-386

Sears, S., Kraus, S. (2009). I think therefore I Om: Cognitive distortions and coping style as mediators for the effects of mindfulness meditation on anxiety, positive and negative affect, and hope. Journal of Clinical Psychology. 65. 561-573.

Szabó K.G., Vargha J.L., Balázsi R., Bartalus J., Bogdan V.(2011). Measuring psychological flexibility:preliminary data on the psychometric properties of the romaniai version of the Acceptance and Action Questionnaire (AAQ-II). Journal of Cognitive and Behavioral Psychotherapies, 11. 1. 67-82.

Tanner, M.A., Travis, F., Gaylord-King, C., Haaga, D.A.F., Grosswald, S., Schneider, R.H. (2009). The effects of the Transcendental Meditation program on mindfulness. Journal of Clinical Psychology. 65. 574-589 
Teasdale, J.D., Segal, Z.V., Williams, J.M.G., Ridgeway,V. A., Soulsby, J. M., Lau, M. A. (2000). Prevention of relapse/recurrence in major depression by mindfulnessbased cognitive therapy. Journal of Consulting and Clinical Psychology. 68. 615-623

Williams, M., Teasdale, J., Segal, Z., Kabat-Zinn, J. (2011): Kiút a boldogtalanságból. Édesvíz kiadó, Budapest

Williams, K. A., Kolar, M. M., Reger, B. E., Pearson, J. C.(2001). Evaluation of a wellnessbased mindfulness stressreduction intervention: A controlled trial. American Journal of Health Promotion. 15. 6. 422-432. 